\title{
A rare case of plexiform schwannoma of the lower lip: Treatment and management
}

\author{
Subha Dhua \\ Department of Plastic and Reconstructive Surgery, Vydehi Institute of Medical Sciences and Research Centre, Whitefield, \\ Bengaluru, Karnataka, India
}

Address for correspondence: Dr. Subha Dhua, Department of Plastic and Reconstructive Surgery, Vydehi Institute of Medical Sciences and Research Centre, 82, EPIP Area, Whitefield, Bengaluru - 560 066, Karnataka, India. E-mail: subhadhua2015@gmail.com

\section{ABSTRACT}

An 18-year-old female presented with a swelling on the lower lip, which was insidious in onset and gradually progressive. The mass was completely excised under local anaesthesia. Complete histopathologic and immunohistochemical studies were conducted. The Antoni A areas were found along with typical verocay bodies composed of palisading nuclei and surrounding spaces filled with eosinophilic filaments. No necrosis was noted and there were no atypical mitotic figures. In the Antoni $B$ region, a closely textured matrix with areas of edema, myxomatous changes, cystic degeneration and dilated vessels were noted. On the basis of the histopathologic and immunohistochemical staining with S-100 protein, a diagnosis of plexiform schwannoma was made and has been reported in this study. The post-operative view confirmed complete recovery after 6 weeks of surgery. This is a rare case with the tumour located in the lower lip, as very few cases have been reported in literature and it may be the first one reported from India.

\section{KEY WORDS}

Antoni A; S-100 protein; T1-weighted images; verocay bodies

\section{INTRODUCTION}

P lexiform schwannoma of the lower lip is a rare neurogenic tumour arising from the peripheral neural sheath and is also called as neurilemmoma or neurinoma. It is an uncommon benign, true nerve sheath neoplasm formed entirely of Schwann cell proliferation that occurs in the central and peripheral nerves. It is a solitary, benign, slow-growing, smooth-surfaced and non-tender mass and is known

\begin{tabular}{|l|l|}
\hline \multicolumn{2}{|c|}{ Access this article online } \\
\hline Quick Response Code: & Website: \\
\hline & www.ijps.org \\
\hline & Dol: \\
\hline
\end{tabular}

to predominantly affect young adults. There is no sex predilection and it commonly manifests as an asymptomatic, slow-growing and solitary nodule (Kun et al. 1993, Michida et al. 1995, Fitzpatrik 1996)..1] Lower lip is a rare location for plexiform schwannoma, with very few cases reported in the literature $\mathrm{e}^{[2,3]}$ as shown in Table 1.

\footnotetext{
This is an open access article distributed under the terms of the Creative Commons Attribution-NonCommercial-ShareAlike 3.0 License, which allows others to remix, tweak, and build upon the work non-commercially, as long as the author is credited and the new creations are licensed under the identical terms.
}

For reprints contact: reprints@medknow.com

How to cite this article: Dhua S. A rare case of plexiform schwannoma of the lower lip: Treatment and management. Indian J Plast Surg 2015;48:208-11. 


\section{CASE REPORT}

An 18-year-old female patient was apparently normal 10 years back when she developed swelling of lower lip which was insidious in onset and gradually progressive. It was of size $1 \mathrm{~cm} \times 1 \mathrm{~cm}$ initially and had gradually increased to $3 \mathrm{~cm} \times 3 \mathrm{~cm}$.

Physical examination revealed a slow-growing, smoothsurfaced and non-tender mass measuring $3 \mathrm{~cm} \times 3 \mathrm{~cm}$ located in the vermilion area of the lower lip [Figure 1a and b].

There was no history of discharge or pain. Laboratory test results revealed peripheral hypercellular (Antoni A) and central hypocelluler (Antoni B) regions.

Fibroma, neurofibroma, plexiform schwannoma, leiomyoma, minor salivary gland tumour and other benign mesenchymal tumours were considered in the differential diagnosis of this mass of the lower lip.

Table 1: Reported cases of benign plexiform schwannomas

\begin{tabular}{lccll}
\hline Authors (year) & $\begin{array}{c}\text { Number } \\
\text { of cases }\end{array}$ & $\begin{array}{c}\text { Age } \\
\text { (years) }\end{array}$ & Sex & Location \\
\hline Das Gupta et al. (1969) & 3 & NA & NA & NA \\
Cherrick et al. (1971) & 1 & NA & NA & NA \\
Barbosa et al. (1984) & 1 & 36 & Male & Upper lip \\
Asaumi et al. (2000) & 1 & 20 & Female & Upper lip \\
Yang, Shiah-Wei et al. & 1 & 22 & Female & Upper lip \\
(2003) & & & & \\
Yilmaz et al. (2004) & 1 & 29 & Female & Lower lip \\
Baderca et al. (2008) & 1 & 25 & Male & Lower lip \\
Lobo et al. (2009) & 1 & 7 & Male & Lower lip \\
Jurkovic et al. (2009) & 1 & 72 & Male & Lower lip \\
Cardoso et al. (2010) & 1 & 52 & Male & Lower lip \\
Mourouzis et al. (2011) & 1 & 16 & Male & Lower lip \\
Present case & 1 & 18 & Female & Lower lip \\
\hline
\end{tabular}

NA: Data not available

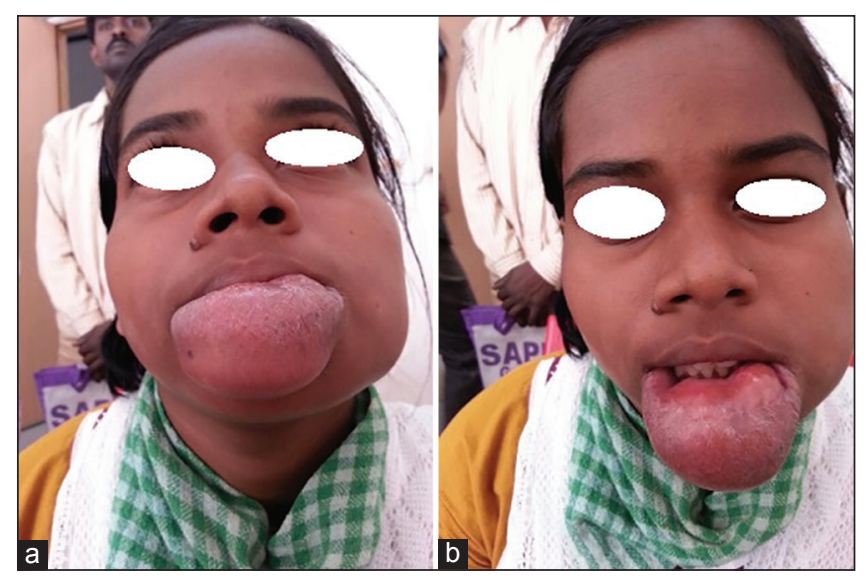

Figure 1: $(a$ and $b)$ Plexiform schwannoma of the lower lip

\section{Procedure}

The mass was excised under local anaesthesia. It was an encapsulated tumour mass measuring $3 \mathrm{~cm} \times 3 \mathrm{~cm}$, with a fairly firm and smooth surface [Figure $2 a$ and $b$ ].

The post-operative view immediately after surgery is presented in Figure 3a, and full recovery was evident 6 weeks after surgery [Figure 3b].

\section{Histopathologic studies}

The histopathologic studies of the tumour mass showed typical verocay bodies composed of palisading nuclei and surrounding spaces filled with eosinophilic filaments in Antoni A area. No necrosis was noted and there were no atypical mitotic figures. In Antoni B region, a closely textured matrix with areas of oedema, myxomatous changes, cystic degeneration, and dilated vessels were noted.

On the basis of histopathologic findings and immunohistochemical profile, a diagnosis of plexiform schwannoma was arrived $\mathrm{at}^{\left[{ }^{[4]}\right.}$ [Figure $\left.4 \mathrm{a}-\mathrm{c}\right]$.

Microscopically, the characteristic histological features of schwannoma of lip are similar to those of analogous lesions found at other sites. These include complete tumour encapsulation and composition consisting of alternating regions of hypercellularity and hypocellularity known as Antoni A and Antoni B areas respectively. ${ }^{[5,6]}$ In general, the relative proportions of the two regions vary to the extent that either of them may occupy nearly the entire tumour. Usually, the hypercellular Antoni A region consists of monomorphic spindle-shaped Schwann cells with pointed basophilic nuclei and poorly defined eosinophilic cytoplasm. Occasionally, verocay bodies, made up of palisading spindle-shaped cells around eosinophilic fibrils, are present in Antoni A area as noted in our case [Figure 4a-c]. ${ }^{.7]}$ Further, secondary changes, such as cystic degeneration, vessels with thick hyaline walls, and haemorrhage [Figure 4a-c], may occur in

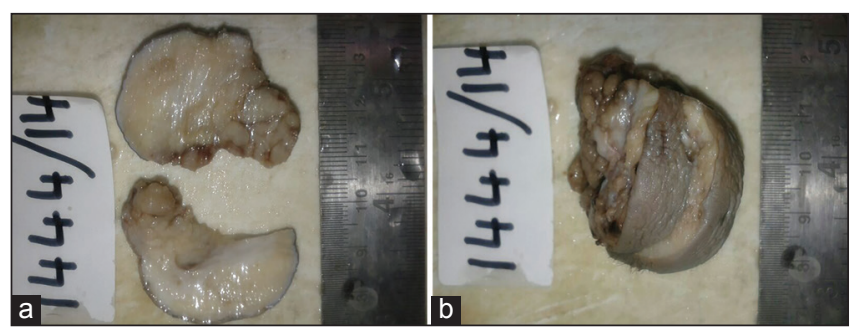

Figure 2: $(a$ and $b)$ Encapsulation of the tumour with the plexiform schwannoma tissue of the lip $(3 \mathrm{~cm} \times 3 \mathrm{~cm})$

Indian Journal of Plastic Surgery May-August 2015 Vol 48 Issue 2 


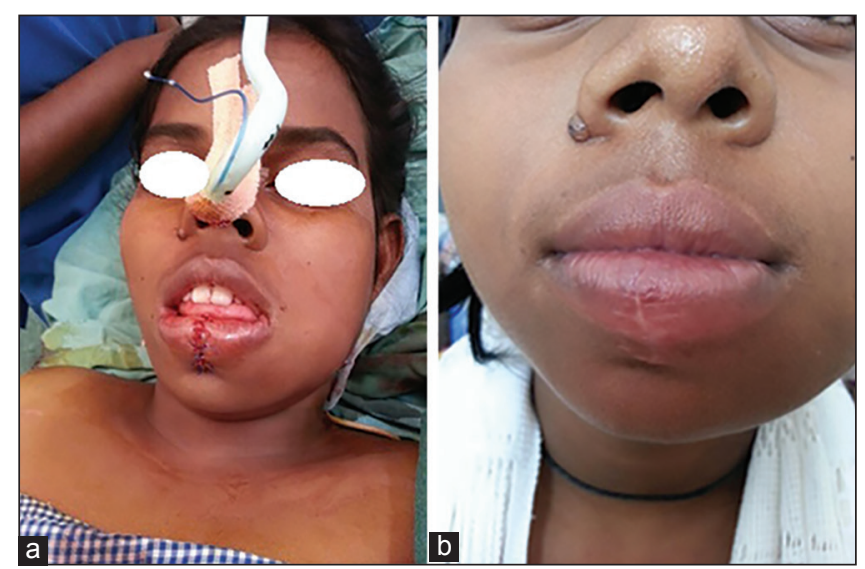

Figure 3: Post-operative view of the lip after removal of the tumour - ( $a$ and $b$ ) Post-operative view of the lip 6 weeks after surgery

Antoni B tissue..$^{[2,6,8-10]}$ These secondary changes were also observed in the present case.

Mitosis and necrosis were not detected; however, a loosely textured matrix was found in Antoni B tissue, with areas of oedema, myxomatous changes, cystic degeneration and presence of dilated hyaline vessels. Immunohistochemical staining was strongly positive for S-100 protein.

Intense S-100 protein immunoreactivity for cytoplasmic and nuclear patterns indicates neural origin. ${ }^{[1,6]}$ These staining results and associated $\mathrm{H}$ and $\mathrm{E}$ microscopic findings confirmed the diagnosis of plexiform schwannoma in the reported case.

The overall prognosis of plexiform schwannoma is quite favourable. Conservative surgical removal with a wide excision is the treatment of choice and there is no recurrence. ${ }^{[2,5,8]}$

As these rare plexiform schwannoma tumours are non-specific in presentation, clinical diagnosis becomes difficult. Therefore, differential diagnosis may include fibroma, pleomorphic adenoma and other salivary gland tumours. $^{\mid 5]}$

\section{DISCUSSION}

Plexiform schwannomas are uncommon benign, solitary, encapsulated neoplasms arising predominantly from both peripheral and intracranial portions of cranial nerves in the head and neck region, whereas peripheral cranial nerve plexiform schwannomas are usually located in the parapharyngeal space of neck and in soft tissues

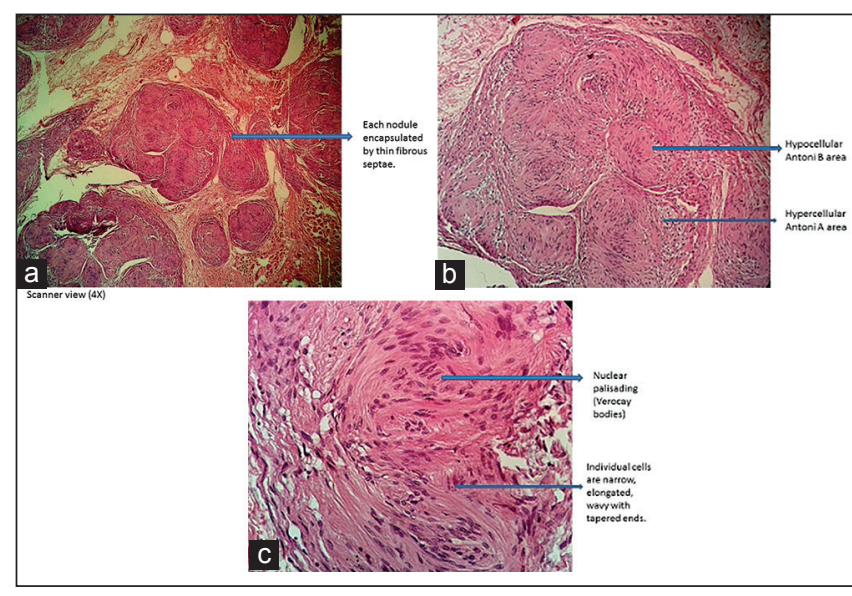

Figure 4: Post-operative view of the lip 6 weeks after surgery (a) Scanner view $(\times 4)$ - micrograph showing each nodule encapsulated by thin fibrous septae (b) Low power view $(\times 10)$ : Biphasic arrangement of cells hypocellular Antoni B area and hypercellular Antoni A area (c) High power view $(\times 40)$ - showing nuclear palisading (verocay bodies) and individual cells are narrow, elongated, wavy with tapered ends

such as tongue, buccal mucosa, palate and gingiva. ${ }^{[3]}$ In the parapharyngeal space, the most commonly involved nerves are vagus and cervical sympathetic chain. In 1969, Das Gupta et al..$^{[3]}$ described plexiform schwannoma with lip as a rare area of occurrence followed by palate and buccal mucosa.

Most commonly, plexiform schwannomas are characterized by their solitary occurrence with relatively smooth surface and slow growth.

The characteristic histological features of plexiform schwannoma of lip are fairly similar to those of analogous lesions found at other sites. The tumour has two distinct patterns which are described as Antoni A and Antoni B areas, and the relative proportions of these two areas vary considerably. The Antoni A hypercellular areas primarily consist of monomorphic spindle-shaped Schwann cells with pointed basophilic nuclei and poorly defined eosinophilic cytoplasm..$^{[2,6,8]}$ Antoni B areas consist of loosely arranged cells and small cystic spaces. In Antoni B areas, cystic degeneration, vessels with thick hyaline walls, and haemorrhage were observed..$^{[7,8]}$ Immunohistochemically, positive S-100 protein and level-7 antigen reactivity confirm the Schwann cell nature of these tumours. ${ }^{[1]}$

For plexiform schwannomas of lip, ultrasound, computed tomography and magnetic resonance imaging are also used for preoperative diagnosis. Homogeneous, hypoechoic features and posterior acoustic enhancement are seen on ultrasound. Computerized tomography 
shows homogeneous soft tissue density mass with clear margins and magnetic resonance imaging shows a homogenous lesion with low intermediate signal intensity on T1-weighted images and high signal intensity on T2weighted images. ${ }^{[6]}$

Histopathologic examination is used for confirmation, and the case presented here was confirmed only with histopathologic examination.

\section{Financial support and sponsorship}

Nil.

\section{Conflicts of interest}

There are no conflicts of interest.

\section{REFERENCES}

1. Kun Z, Qi DY, Zhang KH. A comparison between the clinical behavior of neurilemmomas in the neck and oral and maxillofacial region. J Oral Maxillofac Surg 1993;51:769-71.
2. Baderca F, Cojocaru S, Lazar E, Lazureanu C, Faur A, Lighezan R, et al. Schwannoma of the lip: Case report and review of the literature. Rom J Morphol Embryol 2008;49:391-8.

3. Das Gupta TK, Brasfield RD, Strong EW, Hajdu SI Benign solitary schwannomas (neurilemomas). Cancer 1969; 24:355-66.

4. Cardoso CL, Tolentino Ede S, Capelozza AL, Consolaro A. Schwannoma in the lower lip mucosa: Unexpected diagnosis. Quintessence Int 2010;41:769-71.

5. Asaumi J, Konouchi H, Kishi K. Schwannoma of the upper lip: Ultrasound, CT, and MRI findings. J Oral Maxillofac Surg 2000;58:1173-5.

6. Pahwa R, Khurana N, Uma CK, et al. Neurilemmoma of tongue. Ind J Oral Surg 1968;26:651-8.

7. Cherrick HM, Eversole LR. Benign neural sheath neoplasm of the oral cavity. Report of thirty-seven cases. Oral Surg Oral Med Oral Pathol 1971;32:900-9.

8. MichidaA, Ryoke K, Ishikura S, Hamada T. Multiple schwannomas of the neck, mediastinum, and parapharyngeal space: Report of case. J Oral Maxillofac Surg 1995;53:617-20.

9. Triaridis C, Tsalighopoulos MG, Kouloulas A, Vartholomeos A. Posterior pharyngeal wall schwannoma (case report). J Laryngol Otol 1987; 101:749-52.

10. De Bree R, Westerveld GJ, Smeele LE. Submandibular approach for excision of a large schwannoma in the base of the tongue. Eur Arch Otorhinolaryngol 2000;257:283-6. 